\title{
Morphophysiology of Germination among Seeds of Pau-rainha (Centrolobium paraense) Collected in the State of Roraima
}

\author{
Luís Augusto Melo Schwengber ${ }^{1}$, Oscar José Smiderle ${ }^{2}$, Aline das Graças Souza ${ }^{3}$, José Maria Arcanjo Alves ${ }^{1}$, \\ Dalton Roberto Schwengber ${ }^{2}$ and Cylles Zara dos Reis Barbosa ${ }^{1}$ \\ 1. Postgraduate Program in Agronomy, Universidade Federal de Roraima (UFRR), Boa Vista, RR, CEP 69300-000, Brazil \\ 2. Brazilian Agricultural Research Corporation-Embrapa Roraima, Boa Vista, RR, CEP 69301-970, Brazil \\ 3. Laboratory of Plant Tissue Culture, Federal University of Pelotas, Campus Capão do Leão, RS, CEP 96010-900, Brazil
}

\begin{abstract}
This work intended to characterize the seed morphology, water absorption patterns and to determine the vigor among different colored seeds of the species Centrolobium paraense (Fabaceae). For this purpose, samaras which were opened were collected from two sites-Água Boa (AB) and Taiano (TAI) located in the state of Roraima, and the seeds screened by the coat coloration (light brown/intermediate brown/dark brown) for four conditions (two sites and two years of collection). Evaluation of water absorption by the seeds at different periods, mass of 1,000 seeds, water content, electrical conductivity (EC), seedling emergence and emergence velocity (EV) were performed. The water absorption by the seeds of Centrolobium paraense indicates coat permeability to water and distinct absorptions according to coat colorations. The EC test is efficient in determining the physiological quality of seeds of Centrolobium paraense. Seed coat coloration affects the physiological quality of the seeds of Centrolobium paraense. It is possible to distinguish the seeds of $\mathrm{AB}$ and TAI into two degrees of physiological quality, the light brown-colored seeds being more vigorous.
\end{abstract}

Key words: Centrolobium paraense, water absorption curve, electrical conductivity, seed vigor, seed coloring.

\section{Introduction}

The demand for seedlings of native forest species has been growing due to crescent consciousness on the need for environmental protection and to environmental restoration programs [1]. Species of the genus Centrolobium have been designated as priorities for reforestation in natural areas, however, in spite of their importance, few studies have been conducted about this genus.

There are five species in Brazil, i.e., Centrolobium microchaete (Mart. ex Benth.) H.C. Lima, Centrolobium paraense Tul., Centrolobium robustum (Vell.) Mart. ex Benth., Centrolobium sclerophyllum H. C. Lima and Centrolobium tomentosum Guillem.

Corresponding author: Oscar José Smiderle, Ph.D., research field: seed technology. ex Benth.. In Roraima, Centrolobium paraense (pau-rainha) occurs in spots of semi-deciduous forests and forest-covered hills scattered through the savannah region [2]. Since most of native forest species are propagated via seed, knowledge concerning morphophysiology is fundamental, as specific environmental conditions are necessary for each species to attain germination [3]. Adequate methods for seed analysis of forest species have been the object of great interest, especially when aiming at obtaining information expressing the physiological quality of seed [4].

Seeds differ according to coat color, and this heteromorphy, observed in genera of Fabaceae family, is associated with seed physiological quality (germination, vigor) and has been employed to find the ideal class aiming the multiplication of several 
plant species [5]. For a great number of species, classification by seed coat coloring is a strategy, which may be adopted to make the emergence of seedlings uniform and to obtain young plants of similar size and/or more vigorous [6]. In this context, knowledge concerning water absorption by seeds in different coats at cell membrane level is of great importance [7]. During seed imbibition, important changes which are not detected by germination test take place [8]. For that reason, the most utilized is the electrical conductivity (EC) test, through which, it is possible to analyze the organization level of cell membranes, quantifying the exudates present in the aqueous solutions of the immersed seeds [9].

Research concerning the morphophysiological aspects during seed germination of Centrolobium paraense becomes highly relevant due to environmental adversities found in the tropical ecosystems. It was intended in the present work to characterize the seed morphology, to obtain water absorption patterns from seeds with different coat colors and to determine the vigor of seeds of Centrolobium paraense.

\section{Materials and Methods}

This study was conducted at Embrapa Roraima, in the Seed Analysis Laboratory (LAS) and in greenhouse, respectively, during the period from May to November of 2014, both located on BR 174, $\mathrm{Km} 8$, Industrial District, under geographic reference coordinates $02^{\circ} 45^{\prime} 28^{\prime \prime} \mathrm{N}, 60^{\circ} 43^{\prime} 54^{\prime \prime} \mathrm{W}$ and $90 \mathrm{~m}$ of altitude. The species utilized was Centrolobium paraense, whose fruits (samaras) were collected in February/March of 2013 and 2014, from two distinct sites, one at Água Boa (AB) region $\left(02^{\circ} 43^{\prime} 39.5^{\prime \prime} \mathrm{N}\right.$ and $60^{\circ} 51^{\prime} 35.4^{\prime \prime} \mathrm{W}$; Datum: WGS84) and the other at Taiano (TAI) village $\left(03^{\circ} 06^{\prime} 46.7^{\prime \prime} \mathrm{N}\right.$ and $60^{\circ} 49^{\prime} 38.6^{\prime \prime}$ W; Datum: WGS84), both in the state of Roraima. All collected fruits were kept intact in opened $50 \mathrm{~L}$ polypropylene bags under environment conditions and protected of rain. In April 2014, fruits from 2013 and
2014 collections were opened for seed extraction and subsequent studies.

Boa Vista lies in the tropical climatic zone. The climate in the region is, according to Köppen, of the Aw type: (rainy tropical with a short period of drought) with annual average rainfall between $1,700 \mathrm{~mm}$ and $2,000 \mathrm{~mm}$ [10]. The rainy period occurs with the greatest frequency from April to August with monthly totals above $100 \mathrm{~mm}$. From September, rain reduces, beginning a characteristic dry period, lasting more often from November to March [11]. The annual average temperature is of $25.5^{\circ} \mathrm{C}$ [12].

\subsection{Seed Analysis in Laboratory}

Considering the purposes of seed physical and physiological characterization, the seeds were screened by seed coat coloration, being visually classified into light brown, intermediate brown or dark brown, for each of the four conditions (two sites and two years of collection).

Mass of 1,000 seeds was determined according to seed analysis rules (RAS) [13], utilizing four replications of 100 seeds, for every one of the three seed coat colors (light brown, intermediary brown and dark brown) to each of the four conditions of evaluation (two sites and two years of collection). Water content percentage (\%) was calculated in relation to the initial mass of seeds for each treatment. In this way, the oven method at $105 \pm 3{ }^{\circ} \mathrm{C}$ during 24 $\mathrm{h}$ was used [13] with four replications of 10 seeds. The calculation was carried out on wet basis, and the moisture degree was expressed in percentage.

Considering imbibition, seeds were previously weighted in a digital balance with precision of $0.001 \mathrm{~g}$

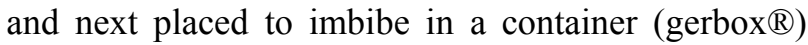
padded with two sheets of distilled water-moistened filter paper according to RAS [13]. The final result obtained by arithmetic mean was expressed in percent basis. In order to obtain the water absorption curve, four replications of 10 seeds were utilized respectively for light brown, intermediate brown or dark brown 
seeds collected at $\mathrm{AB}$ and TAI in the years of 2013 and 2014 [14]. These seeds were taken out of the containers, their surface moisture removed, weighted on precision balance of $0.001 \mathrm{~g}$ and subsequently placed again to imbibe. The determinations were conducted every $6 \mathrm{~h}$ during the first $24 \mathrm{~h}$. Subsequent determinations were performed every $12 \mathrm{~h}$ and $24 \mathrm{~h}$ during a 312-h period.

Concerning electric conductivity (EC) test, 25 seeds, with no visible physical damages, were placed into 75 $\mathrm{mL}$ of distilled water in $180 \mathrm{~mL}$ plastic glasses, with four replications. The samples remained for $24 \mathrm{~h}$ in a germinator at $25{ }^{\circ} \mathrm{C}$ and the $\mathrm{EC}$ of the leachates was measured by a calibrated digital conductivity meter (Quimis) [15]. The obtained conductivity meter values were divided by respective dry masses of 25 seeds, before immersion into distilled water and in the same way by wet masses verified after $24 \mathrm{~h}$ immersion. The results were expressed in $\mu \mathrm{S} / \mathrm{cm} / \mathrm{g}$ of seed.

\subsection{Seed Analysis in Greenhouse}

Determination of seedling emergence was accomplished by sowing 200 seeds into a sand seed bed inside a greenhouse with four replications of 50 seeds each. The percentage of normal, abnormal seedlings and dead seeds were obtained $30 \mathrm{~d}$ after sowing. Seeds were then removed of the substrate, and next evaluated according to criteria: normal seedling, abnormal seedling and dead seed. Percentage of emergence was calculated as Eq. (1), proposed by Vieira [16]:

Emergence percentage $(\%)=(\mathrm{Ne} / \mathrm{Ae}) \times 100$ where, $\mathrm{Ne}=$ number of seedlings emerged in the seed bed and $\mathrm{Ae}=$ total number of seeds placed to emerge.

Seedling emergence velocity (EV) was determined together with emergence, with daily counting of normal seedlings from beginning of seedling emergence up to $30 \mathrm{~d}$. EV was calculated by Eq. (2) proposed by Maguire [17]:

$$
\mathrm{EV}=\left(N_{1} / T_{1}\right)+\left(N_{2} / T_{2}\right)+\ldots+\left(N_{n} / T_{n}\right)
$$

where, $N_{1}=$ number of seedlings emerged in the first counting; $T_{1}=$ number of days elapsed till the first counting; $N_{2}=$ number of seedlings emerged in the second counting; $T_{2}=$ number of days elapsed till the second counting; $n=$ last counting.

The experimental design utilized was the completely randomized (CRD) with four replications. The results were submitted to analysis of variance through $F$ test at $5 \%$ of probability and the means were compared by Tukey test ( $\alpha=5 \%$ ), utilizing the Sisvar software [18]. Concerning data on water absorption by the seeds, regression analysis at $5 \%$ of probability was carried out for adjustment of the model which best represented the curve.

\section{Results}

\subsection{Color of Seed Coats}

Opening of Centrolobium paraense samaras resulted into seeds presenting coats with three predominant coloring (light brown, intermediate brown and dark brown) and with different percents according to sites and years of collection. In 1,087 samaras obtained in each year (2013 and 2014) from $\mathrm{AB}, 32.1 \%$ and $33.5 \%$ presented light brown-colored tegument, $27.7 \%$ and $36.4 \%$ intermediate brown and $31.4 \%$ and $38.7 \%$ dark brown, respectively. In 1,087 samaras collected in each year (2013 and 2014) in TAI, $30.3 \%$ and $43.3 \%$ presented light brown-colored coat, $39.9 \%$ and $36.4 \%$ intermediate brown and $29.7 \%$ and $20.3 \%$ dark brown seed coats, respectively. It was also verified that there were samaras in which all seeds presented distinct colorations (Fig. 1).

\subsection{Morphological Characterization of Seeds}

Regarding to physical characterization of Centrolobium paraense seeds, water content of $6.48 \%$, $5.97 \%$ and $6.24 \%$ was found in seeds collected in 2013 and of $6.59 \%, 6.35 \%$ and $6.73 \%$ in those collected in 2014, respectively for seeds with light brown, intermediate brown and dark brown colored seed coats.

As shown in Table 1, the average values of mass of 


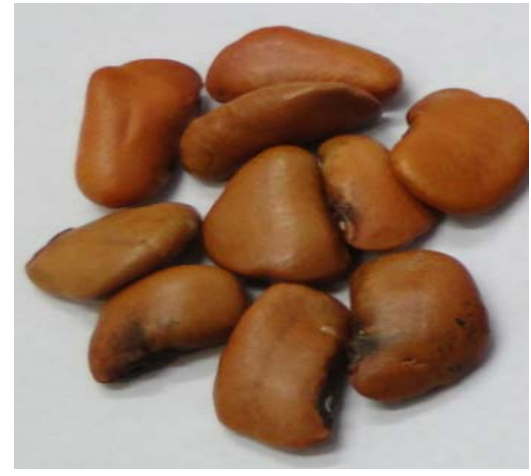

(a) Light brown

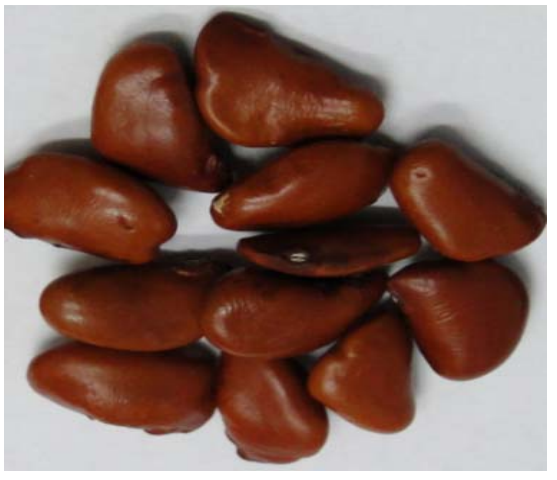

(b) Intermediate brown

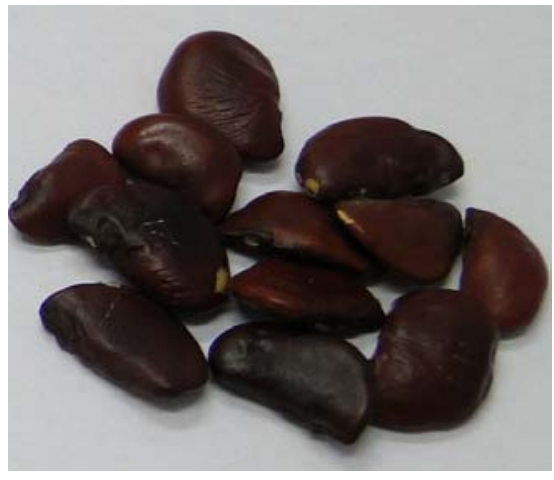

(c) Dark brown

Fig. 1 Classification in relation to seed coat color of Centrolobium paraense collected in ÁB and TAI, RR, in 2013 and 2014 $(n=1,087)$.

Table 1 Average values of mass of 100 and 1,000 seeds of Centrolobium paraense collected in AB and TAI, RR, in 2013 and 2014.

\begin{tabular}{lllllll}
\hline Site & Color of seed coat & $\begin{array}{l}\text { Mass of 100 seeds } \\
(\mathrm{g})\end{array}$ & Variance & DP & CV\% & $\begin{array}{l}\text { Mass of 1,000 seeds } \\
(\mathrm{g})\end{array}$ \\
\hline AB 2013 & Light Brown & $28.52^{\mathrm{b}}$ & 26.843 & 5.181 & 18.2 & 285.2 \\
AB 2013 & Intermediate & $30.84^{\mathrm{ab}}$ & 8.890 & 2.982 & 9.7 & 308.4 \\
AB 2013 & Dark Brown & $33.32^{\mathrm{a}}$ & 15.977 & 3.997 & 12.0 & 333.2 \\
Mean & & & & & 308.9 \\
\hline AB 2014 & Light Brown & $33.92^{\mathrm{a}}$ & 15.910 & 3.989 & 11.8 & 339.2 \\
AB 2014 & Intermediate & $33.96^{\mathrm{a}}$ & 15.123 & 3.889 & 11.5 & 339.6 \\
AB 2014 & Dark Brown & $29.84^{\mathrm{b}}$ & 35.473 & 5.956 & 20.0 & 298.4 \\
Mean & & & & & 325.7 \\
\hline TAI 2013 & Light Brown & $26.24^{\mathrm{c}}$ & 16.357 & 4.044 & 15.4 & 262.4 \\
TAI 2013 & Intermediate & $34.12^{\mathrm{a}}$ & 21.193 & 4.604 & 13.5 & 341.2 \\
TAI 2013 & Dark Brown & $30.04^{\mathrm{b}}$ & 36.790 & 6.065 & 20.2 & 300.4 \\
Mean & & & & & 301.3 \\
\hline TAI 2014 & Light Brown & $33.28^{\mathrm{b}}$ & 17.293 & 4.159 & 12.5 & 332.8 \\
TAI 2014 & Intermediate & $37.76^{\mathrm{a}}$ & 27.273 & 5.222 & 13.8 & 377.6 \\
TAI 2014 & Dark Brown & $32.48^{\mathrm{b}}$ & 43.177 & 6.571 & 20.2 & 324.8 \\
Mean & & & & & 345.1 \\
\hline CV\% & & 15.84 & & &
\end{tabular}

DP: standard deviation; CV: coefficient of variation.

${ }^{\mathrm{a}-\mathrm{c}}$ In the column, means followed by the same letter did not differ statistically from one another by the Tukey's test at the level of $5 \%$ of probability.

1,000 seeds from $\mathrm{AB}$ collected in 2013 and in 2014 were $308.9 \mathrm{~g}$ and $325.73 \mathrm{~g}$, respectively, and from TAI in 2013 and 2014 collection years were $301.3 \mathrm{~g}$ and $345.1 \mathrm{~g}$, respectively. The average values of mass of 100 seeds were obtained with variance; standard deviation and coefficient of variation showed next to each value, and comparison of means within the four environments presented coefficient of variation of $15.84 \%$ (Table 1).
Water absorption curves of Centrolobium paraense seeds exhibited in Figs. 2 and 3 showed significant differences for the four environments. Thus, they were represented separately for each location and year of collection (environments), allowing the identification of the distinct tendencies of the seeds of Centrolobium with light brown, intermediate brown and dark brown-colored seed coats.

According to water absorption curves, dark 
brown-coated seeds when compared to seeds with light and intermediate brown coats showed more accentuated water absorption at all times. Among seeds collected in AB in the years of 2013 (Fig. 2a) and 2014 (Fig. 2b), seeds with light brown colored coat showed the least amounts of water absorption. Considering seeds of intermediate brown colored seed coat from TAI collected in 2013 (Fig. 3a), there was a high increase in water absorption during the first hour of imbibition, followed by an slow and constant increment during the following hours, until the emission of the primary root, preventing the accurate determination of the germination phases of seeds.
Considering the percentage of seedling emergence, significant viability differences of Centrolobium paraense seeds concerning two locations and two years of collection (AB 2013 and 2014, TAI 2013 and 2014) are observed. Seeds with light brown seed coat coming from TAI in 2014 presented the greater seedling emergence and $\mathrm{EV}$, followed by intermediate brown seeds and by dark brown seeds (Table 2). This shows that the percentage of seedling emergence and EV were efficient in differentiating seed vigor.

Light brown seeds in both environments and years of collection imbibed less water, presenting the greater
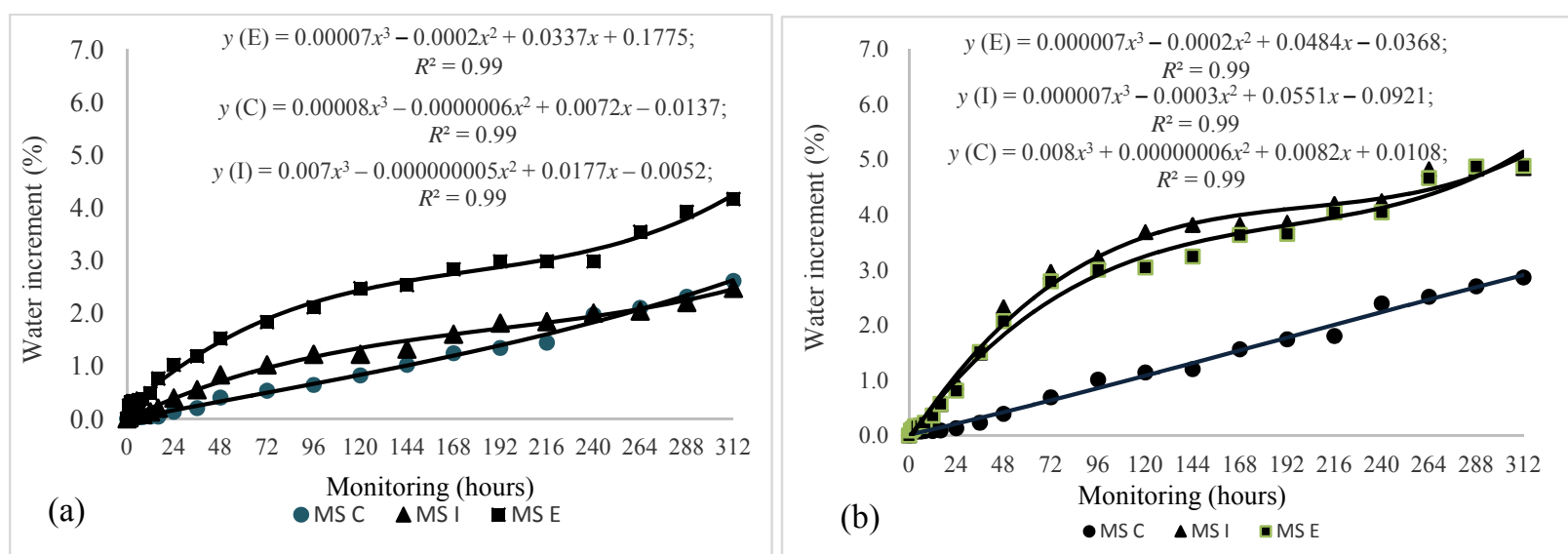

Fig. 2 Water absorption curves from seeds of Centrolobium paraense with light brown, intermediary brown and dark brown colored tegument collected in ÁB in 2013 (a) and 2014 (b).

MS C = light brown-colored tegument; MS I = seed with intermediary brown-colored tegument; MS E = seed with dark-colored tegument.
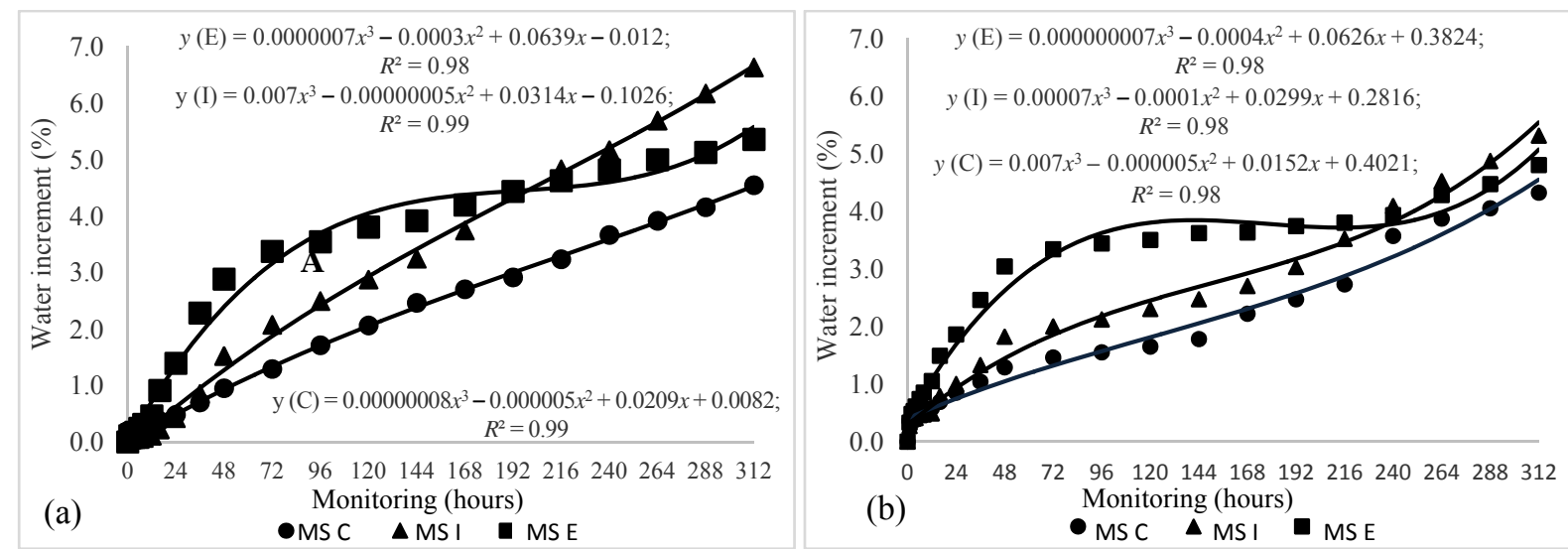

Fig. 3 Water absorption curves from seeds of Centrolobium paraense with light brown, intermediary brown and dark brown -colored tegument collected in TAI in years of 2013 (a) and 2014 (b).

MS C = seed with light brown-colored tegument; MS I = seed with intermediary brown-colored tegument and MS E = seed with dark brown-colored tegument. 
Table 2 Average values of initial mass (IM), electric conductivity (EC and EC after 24 h), wet mass (WM), seedling emergence (SE) and emergence velocity index (EV) obtained for seeds (light brown, intermediate brown and dark brown) of Centrolobium paraense collected in four conditions in Roraima.

\begin{tabular}{|c|c|c|c|c|c|c|c|}
\hline \multirow{2}{*}{ Site } & \multirow{2}{*}{ Color of seed coat } & \multirow{2}{*}{$\begin{array}{l}\text { IM } \\
(\mathrm{g})\end{array}$} & $\mathrm{EC}$ & EC after $24 \mathrm{~h}$ & \multirow{2}{*}{$\begin{array}{l}\text { WM } \\
(\mathrm{g})\end{array}$} & \multirow{2}{*}{ SE $(\%)$} & \multirow{2}{*}{ EV } \\
\hline & & & & $\mathrm{cm} / \mathrm{g})$ & & & \\
\hline AB 2013 & Light & $23.98^{\mathrm{b}}$ & $20.63^{\mathrm{a}}$ & $17.97^{\mathrm{a}}$ & $32.0^{\mathrm{b}}$ & $71^{\mathrm{a}}$ & $3.73^{\mathrm{a}}$ \\
\hline AB 2013 & Intermediary & $31.92^{\mathrm{a}}$ & $47.91^{\mathrm{b}}$ & $30.11^{b}$ & $50.7^{\mathrm{a}}$ & $51^{\mathrm{b}}$ & $2.38^{\mathrm{b}}$ \\
\hline AB 2013 & Dark & $31.74^{\mathrm{a}}$ & $75.56^{\mathrm{c}}$ & $43.68^{c}$ & $55.1^{\mathrm{a}}$ & $41^{\mathrm{c}}$ & $1.95^{\mathrm{c}}$ \\
\hline AB 2014 & Light & $31.74^{\mathrm{c}}$ & $46.08^{\mathrm{a}}$ & $27.87^{\mathrm{a}}$ & $52.4^{\mathrm{c}}$ & $57^{\mathrm{a}}$ & $3.83^{\mathrm{a}}$ \\
\hline AB 2014 & Intermediary & $32.40^{\mathrm{b}}$ & $59.49^{\mathrm{b}}$ & $34.63^{b}$ & $58.5^{\mathrm{b}}$ & $51^{\mathrm{a}}$ & $2.77^{\mathrm{b}}$ \\
\hline AB 2014 & Dark & $34.16^{\mathrm{a}}$ & $61.73^{b}$ & $35.47^{\mathrm{b}}$ & $63.6^{\mathrm{a}}$ & $49^{\mathrm{b}}$ & $2.08^{\mathrm{c}}$ \\
\hline TAI 2013 & Light & $34.61^{\mathrm{a}}$ & $46.33^{\mathrm{a}}$ & $28.24^{\mathrm{a}}$ & $57.3^{\mathrm{a}}$ & $71^{\mathrm{a}}$ & $2.70^{\mathrm{a}}$ \\
\hline TAI 2013 & Intermediary & $34.79^{\mathrm{a}}$ & $60.13^{b}$ & $33.38^{\mathrm{a}}$ & $59.8^{\mathrm{a}}$ & $56^{\mathrm{b}}$ & $2.40^{\mathrm{a}}$ \\
\hline TAI 2013 & Dark & $27.67^{\mathrm{b}}$ & $79.48^{\mathrm{c}}$ & $42.65^{\mathrm{b}}$ & $48.1^{\mathrm{b}}$ & $46^{\mathrm{c}}$ & $2.08^{\mathrm{c}}$ \\
\hline TAI 2014 & Light & $32.13^{c}$ & $25.11^{\mathrm{a}}$ & $17.08^{\mathrm{a}}$ & $47.1^{\mathrm{b}}$ & $79^{\mathrm{a}}$ & $4.17^{\mathrm{a}}$ \\
\hline TAI 2014 & Intermediary & $34.92^{b}$ & $47.03^{b}$ & $29.99^{\mathrm{b}}$ & $54.6^{\mathrm{a}}$ & $60^{\mathrm{b}}$ & $2.71^{\mathrm{b}}$ \\
\hline TAI 2014 & Dark & $35.88^{\mathrm{a}}$ & $54.05^{\mathrm{b}}$ & $33.15^{\mathrm{b}}$ & $58.5^{\mathrm{a}}$ & $47^{\mathrm{c}}$ & $1.94^{\mathrm{c}}$ \\
\hline CV\% & & 1.01 & 11.66 & 11.76 & 5.09 & 8.1 & 22.16 \\
\hline
\end{tabular}

seedling emergence ranging from $41 \%$ to $79 \%$. This indicated that the coloring can be a morphological indicator of maturation stage for seeds of this species. On the other hand, EC test was efficient in differentiating seed vigor among seeds with distinct coat coloring considering the two collecting years (2013 and 2014) and the two collection sites (AB and TAI), showing results similar to the seedling emergence test. Seeds with light brown seed coat coloring presented the greatest vigor, followed by the intermediate brown ones.

\section{Discussion}

Results on seed water content obtained in this work are comparable to most plant species which showed the seed water content between $5 \%$ and $20 \%$ [19], but different from results obtained by Imatomi et al. [20] working with seeds of Casearia sylvestris Swartz (Flacourtiaceae) collected in São Paulo and Paraná, in which obtained values were between $14.5 \%$ and $22.9 \%$, with seeds recently collected and between $7.1 \%$ and $9.9 \%$ for seeds stored for 12 months. Working with seeds of Dalbergia nigra (Fabaceae), Imatomi et al. [20] found values of water contents in two lots of seeds (7.92\% and 8.98\%) higher than those verified in this work with Centrolobium paraense $(6.73 \%)$.

Considering the mass of 1,000 seeds, Ataide et al. [21] described fruit and seed characteristics of Centrolobium paraense collected in Araçá indigenous region, in the state of Roraima and obtained the average weight of $322 \mathrm{~g}$, similarly to the weight verified in the present work. However, Cruz and Carvalho [5] evaluated the morphological standards in seeds of Campomanesia adamantium (Myrtaceae) and found the average mass of $256 \mathrm{~g}$ to $325 \mathrm{~g}$ similar to that reported in the present study. According to Pedreira et al. [22], differences in the seed mass can be promoted by genetic diversity inherent to each species; within the population, the modification in fruit size was related not only to genetic component, but also to environment conditions [23].

The mass of 1,000 seeds obtained from $\mathrm{AB}$ in the collection year of 2014 was $325.73 \mathrm{~g}$, from which it is possible to estimate a weight of about $0.325 \mathrm{~g}$ per seed (Table 1). Therefore, three to four seeds of Centrolobium paraense are necessary to reach $1 \mathrm{~g}$, and $1 \mathrm{~kg}$ of Centrolobium paraense seeds contains on 
average 3,070 seeds. This value differs from those described in the instructions for forest species seed analysis [24], in which the value is 10,600 to 30,000 seeds per kg. Lorenzi [25] also mentioned values close to 30,000 seeds per $\mathrm{kg}$. Variation may occur due to factors, such as the collection site, the age of the parent plants or the water content presented by the seeds [25].

The imbibition behavior observed in the light and intermediate brown colored seeds can not be characterized as the triphasic pattern proposed by Bewley and Black [19], which presents an initial phase of rapid water absorption, followed by a stationary phase, ending with a further increase, which once more, show that the coloration of the seed coats significantly influences water absorption.

Water develops a fundamental role in germination. Trough tissue rehydration, seeds reactivate metabolic activities to support embryo growth. The rate of water absorption by the seed depends on several factors, including species, seed coat permeability, temperature, water availability, hydrostatic pressure and seed/water contact area [26].

Considering Centrolobium paraense seeds of collection years of 2013 and 2014 from TAI, results indicated that water absorption in the first $24 \mathrm{~h}$ was more accelerated, then, became slow, while seeds with brown dark seed coat followed sigmoid curve (Figs. $3 \mathrm{a}$ and $3 \mathrm{~b}$ ), showing that they are water-permeable, not presenting seed coat dormancy.

Regarding triphasic pattern of seed hydration proposed by Bewley and Black [19], it can be inferred that phase I of this process lasted about $96 \mathrm{~h}$, in which the water content showed a constant and significant increase. According to Castro et al. [27], this first phase is purely physical, usually rapid and induces to a relative equilibrium of water content, when occurs initiation of phase II of imbibition. In this second phase, cells of inside of the seed do not absorb further water, because they can no longer expand. It is during this period that the metabolic processes required for embryo growth and the completion of germination are activated. The duration depends mainly on temperature and water potential of the seed. It was noted that phase II began at $96 \mathrm{~h}$ and lasted up to 240 $\mathrm{h}$ when phase III initiated, and lasted until the end of the experiment at $312 \mathrm{~h}$ of imbibition.

Period of each phase varies among species, and the results may be different depending also on the external factors prevailing, as observed by Castro et al. [27] with Jatropha curcas (Euphorbiaceae) (phase I $=32 \mathrm{~h}$; phase II $=116 \mathrm{~h}$ ). However, the triphasic character of the imbibition process in which radical protrusion occurs, is presented in Figs. 2 and 3, in a distinguished way for seeds with light, intermediate and dark brown seed coat.

According to Borghetti and Ferreira [28], seeds with similar seedling emergency may have different germination behavior, similar to that obtained in the current work. As concerning $\mathrm{EV}$, significant differences were found among the three colorings of seeds from AB in both collecting years of 2013 and 2014, while seeds collected in TAI showed significant differences in collecting year of 2014 , that is, it was effective to detect differences of vigor among them.

EC test has proven to be effective in determining the physiological quality (vigor) of other forest species, such as Dalbergia nigra (Fabaceae) [29], Sebastiania commersoniana (Euphorbiaceae) [30], Senna siamea (Fabaceae) [31], Dictyoloma vandellianum (Rutaceae) [32], Jatropha curcas (Euphorbiaceae) [33], Pterogyne nitens (Fabaceae) [21] and Solanum sessiliflorum (Fabaceae) [34].

Decrease of EC values with increase of wet mass of the seeds was found. For most of combinations between seeds and water volume, there was a decrease in EC, corroborating the results of Paula and Santos [32] who found seeds of Dictyoloma vandellianum (Rutaceae) with lower values of EC with increasing imbibition time. Those results indicate that during imbibition, the reorganization of cell membranes take place, capable of reducing the loss of cellular 
constituents, and such recoveries are limited to imbibition period.

Correlations between EC and germination highlight alterations occurring in seeds during imbibition period, as well as signaling the deterioration process. It is possible that at the temperature of $22{ }^{\circ} \mathrm{C}$, the correlation is related to the recovery of cell membranes during the hydration period, with transition of gel to the liquid phase, which results in reduced release of exudates, as demonstrated in the results of EC.

The occurrence of exudates in advanced hydration phases at this temperature may be due to different compositions of fatty acids from phospholipids in different membranes, which composes the cells of the embryo and the cotyledons. Furthermore, it is verified the movement of these substances from the inside of the seed into the environment, and the flow is reduced by the layers of cells, thus composing the different cells of the embryo and the cotyledons.

\section{Conclusions}

As the results of this study, it can be concluded that water absorption of Centrolobium paraense seeds indicates permeability of the seed coat to water and distinct absorption according to seed coat coloring. EC test is effective in vigor differentiation of Centrolobium paraense seeds with three seed tegument coloring, and dark brown-coated seeds of both sites ( $\mathrm{AB}$ and $\mathrm{TAI}$ ) present seedling emergence and EV inferior to the others. Lastly, seed coat color interferes with the physiological quality of seeds of Centrolobium paraense, being possible to distinguish seeds of $\mathrm{AB}$ and $\mathrm{TAI}$ into two degrees of physiological quality and the light brown colored seeds presenting greater vigor.

\section{Acknowledgments}

This study is part of the CNPq/IACTI-RR project. The authors show their appreciation to $\mathrm{CNPq}$ and Embrapa Roraima for the structural and financial support.

\section{References}

[1] Dresch, D. M., Scalon, S. P. Q., Masetto, T. E., and Vieira, M. C. 2012. "Germination of Campomanesia adamantium (Camb.) O. Berg. Seeds under Different Temperatures and Moisture Content of Substrate." Scientia Forestalis 40 (94): 223-9. (in Portuguese)

[2] Nascimento, D. F., Leles, P. S. S., Oliveira-Neto, S. N., Moreira, R. T. S., and Alonso, J. M. 2012. "Initial Growth of Six Forest Species under Different Planting Spacing." Cerne. 18 (3): 159-65. (in Portuguese)

[3] Kaminski, P. E. 2004. Pau-rainha (Centrolobium paraense): Characteristics, Potentialities and Usage. Boa Vista: Embrapa Roraima, 34. (in Portuguese)

[4] Rego, S. S., Nogueira, A. C., Kuniyoshi, Y. S., and Santos, Á. F. 2009. "Germination of Blepharocalyx salicifolius (H.B.K.) Berg. Seeds under Different Substrate and Temperature, Light and Humidity Conditions." Rev. Bras. Sementes 31 (3): 212-20. (in Portuguese)

[5] Cruz, E. D., and Carvalho, J. E. U. 2003. "Fruit Biometry and Seed Germination of Couratari stellata A. C. Smith (Lecythidaceae)." Acta Amazonica 33 (3): 381-8. (in Portuguese)

[6] Dresch, D. M., Scalon, S. P. Q., Masetto, T. E., and Vieira, M. C. 2013. "Germination and Seed of 'Gabioba' Concerning Fruit and Seed Sizes.” Pesq. Agrop. Trop. 43 (3): 262-71. (in Portuguese)

[7] Smiderle, O. J., Silva, V. X., Chagas, E. A., Souza, A. G., Ribeiro, M. I. G., Chagas, P. C., and Souza, O. M. 2015. "Açai Seedling Production: Effect of Substrates and Seeds Size on Germination and Growth of Seedlings." J. of Advances in Agriculture 4 (1): 316-23.

[8] Oliveira, D. L., Smiderle, O. J., Paulino, P. P. S., and Souza, A. G. 2016. "Water Absorption and Method Improvement Concerning Electrical Conductivity Testing of Acacia mangium (Fabaceae) Seeds." Revista Biologia Tropical 64 (4): 1651-60.

[9] Coutinho, W. M., Silva-Mann, R., Vieira, M. G. G. C., Machado, C. F., and Machado, J. C. 2007. "Sanitary and Physiological Qualities of Corn Seeds Submitted to Thermotherapy and to Physiological Conditioning." Fitopatologia Brasileira 32 (6): 458-64. (in Portuguese)

[10] Matos, A. C. B., Borges, E. E. L., and Silva, L. J. 2015. "Germination Physiology of Dalbergia nigra (Vell.) Allemão ex Benth. Seeds under Different Temperatures and Exposure Times." Revista Árvore 39 (1): 115-25. (in Portuguese)

[11] Smiderle, O. J., Souza, A. G., Pedrozo, C. A., and Lima, C. G. B. 2017. "Nutrient Solution and Substrates for "Cedro Doce' (Pochota fendleri) Seedling Production." Rev. 
Brasil. Eng. Agríc. e Ambiental 21 (4): 227-31. (in Portuguese)

[12] Smiderle, O. L., and Souza, A. G. 2016. "Production and Quality of Cinnamomum zeylanicum Blume Seedlings Cultivated in Nutrient Solution." Revista Brasileira de Ciências Agrárias 11 (2): 104-10.

[13] Brazil Ministry of Agriculture, Livestock and Food Supply (MAPA). 2009. Rules for Seed Analysis. Brasília: MAPA/ACS, 399. (in Portuguese)

[14] Smiderle, O. J., Souza, A. G., Chagas, E. A., Souza, M. A., and Fagundes, P. R. O. 2016. "Growth and Nutritional Status and Quality of Khaya senegalensis Seedlings." Rev. Ciênc. Agrárias 59 (1): 47-53.

[15] Smiderle, O. J., Lima, J. M. E., and Paulino, P. P. S. 2013. "Water Absorption Curve among Two Size of Jatropha curcas L. Seeds." Revista Agroambiente On-line 7 (2): 203-8. (in Portuguese)

[16] Vieira, R. D. 1994. "Electrical Conductivity Test." In Vigor Tests in Seeds, edited by Vieira, R. D., and Carvalho, N. M. Jaboticabal: FUNEP, 103-32. (in Portuguese)

[17] Maguire, J. D. 1962. "Speed of Germination-Aid in Selection and Evaluation for Seedling Emergence and Vigor." Crop Science 2 (1): 176-7.

[18] Ferreira, D. F. 2011. "Sisvar: A Computer Statistical Analysis System.” Ciênc. e Agrotec. 35 (6): 1039-42.

[19] Bewley, J. D., and Black, M. 1994. Seeds: Physiology of Development and Germination, 2nd ed.. New York and London: Plenum Press.

[20] Imatomi, M., Perez, S. C. J. G., and Ferreira, A. G. 2009. "Characterization and Germinative Behaviour of Caesaria sylvestris Swartz (Salicaceae) Seeds.” Rev. Bras. Sementes 31 (2): 36-47. (in Portuguese)

[21] Ataide, G. M., Flôres, A. V., Borges, E. E. L., and Resende, R. T. 2012. "Adequacy of the Methodology of Electrical Conductivity Test for Seeds of Pterogyne nitens Tull..” Rev. Bras. Ciênc. Agrárias 7 (4): 635-40. (in Portuguese)

[22] Pedreira, J. L., Hada, A., Pinho, R. C., Miller, R. P., and Alfaia, S. S. 2010. "Use of Pau-rainha Sprouts (Centrolobium paraense Tul.) (Fabaceae: Faboideae): A Way for Local Conservation of the Species in Araçá Indigenous Land, Roraima." Presented at the 61st National Congress of Botany, September 10, 2010, Manaus, Amazonas, Brasil. (in Portuguese)

[23] Nogueira, F. C. B., Medeiros-Filho, S., and Gallao, M. 2010. "Germination Characterization and Fruit, Seed and Seedling Morphologies of Dalbergia cearensis Ducke (Pau-Violeta), Fabaceae.” Acta Bot. Bras. 24 (4): 978-85. (in Portuguese)
[24] Brazil Ministry of Agriculture, Livestock and Food Supply (MAPA). 2013. "Instructions for Forest Species Seed Analysis.” Accessed January 17, 2013. http://www.agricultura.gov.br/assuntos/laboratorios/arqui vos-publicacoes-laboratorio/florestal_documento_pdf-ilo vepdf-compressed.pdf. (in Portuguese)

[25] Lorenzi, H. 2002. Brazilian Trees: Manual for Identification and Cultivation of Brazilian Tree Plants. Nova Odessa: Instituto Plantarum, 368. (in Portuguese)

[26] Cetnarski-Filho, R., and Nogueira, A. C. 2005. "Influence of Temperature on Diaspores Germination of Ocotea odorifera (Vellozo) Rohwer (Canela-Sassafrás)." Ciênc. Florestal. 15 (2): 191-8. (in Portuguese)

[27] Castro, R. D., Bradford, K. J., and Hilhorst, H. W. M. 2004. "Imbibition and Reactivation of Metabolism." In Germination: From Basic to Applied, edited by Ferreira, A. G., and Borghetti, F. Porto Alegre: Artmed, 49-162. (in Portuguese)

[28] Borghetti, F., and Ferreira, A. G. 2004. "Interpretation of Germination Results." In Germination: From Basic to Applied, edited by Ferreira, A. G., and Borghetti, F. Porto Alegre: Artmed, 209-22. (in Portuguese)

[29] Marques, M. A., Paula, R. C., and Rodrigues, J. D. 2002. "Adequation of the Electrical Conductivity Test to Determine the Physiological Quality of Jacaranda-da-Bahia Seeds (Dalbergia nigra (Vell.) Fr. All. ex Benth.)." Rev. Bras. Sementes 24 (1): 271-8. (in Portuguese)

[30] Santos, S. R. G., and Paula, R. C. 2005. "Electric Conductivity Test to Evaluate the Physiological Quality of Seeds of Sebastiania commersoniana (Bail) Smith \& Downs, Euphorbiaceae.” Rev. Bras. Sementes 27 (2): 136-45. (in Portuguese)

[31] Dutra, A. S., Medeiros-Filho, S., and Diniz, F. O. 2007. "Electrical Conductivity Test on Seeds of Senna siamea (Lam.) H. S. Irwin \& Barneby.” Rev. Ciênc. Agronômica 38 (3): 280-5. (in Portuguese)

[32] Paula, J. J. F., and Santos, R. C. 2010. "Accelerated Aging and Electrical Conductivity Tests on Dictyoloma vandellianum A. Juss. Seed.” Scientia Forestalis 38 ( 87): 391-9. (in Portuguese)

[33] Araujo, R. F., Zonta, J. B., Araújo, E. F., Donzeles, S. M. L., and Costa, G. M. 2011. "Electrical Conductivity Test for Jatropha curcas L. Seeds.” Idesia 29 (2): 79-86. (in Portuguese)

[34] Pereira, M. D., and Martins-Filho, S. 2012. "Adequacy of the Methodology of Electrical Conductivity Test for Seeds of Cubi (Solanum sessiliflorum Dunal)." Rev. Agrarian 5 (16): 93-8. (in Portuguese) 